\title{
On a Hidden Aspect of the Credibility Crisis in the European Union
}

\author{
Adam Koronowski \\ Collegium Mazovia \\ ul. Sokołowska 161, 08-110 Siedlce, Poland \\ Tel: +48-512-326-587Ｅ-mail: adam.koronowski@aster.pl
}

Received: November 4, $2010 \quad$ Accepted: November 23, $2010 \quad$ doi:10.5430/rwe.v2n1p38

\begin{abstract}
The financial and economic crisis after year 2007 had an asymmetric impact on the countries of the European Union. While some reasons for this asymmetries are identified, some others remain far from being clearly and openly expressed. In particular, it is not quite obvious why some countries experienced a sharp decline in their credibility in the financial markets. This credibility crisis is commonly explained with poor fiscal stance and high public deficits in the respective countries; Portugal, Ireland, Italy, Greece and Spain (PIIGS). The problem with this explanation is that high public debts and deficits are not specific only to these countries.

Although fiscal stance and public debt are important these countries which were hit most experienced a broader problem of foreign debt crisis which mirrors the situation of the private sector, too. This characteristic of the crisis is blurred by the membership of the countries in the euro zone.

When we accept the diagnosis a question about positive policy actions arises. Unfortunately, fiscal consolidation in the most problematic countries is neither an optimum solution nor a real possibility. Countries which are in the euro zone are unable to use individual monetary and exchange rate policy which seems otherwise a proper instrument in their situation. Moreover, the economic policy of the European Union in the face of the crisis is erratic, in breach of important rules which were supposed to govern economic life in the UE and the euro zone and it does not address in a perspective manner the specific problems encountered by these countries which experience most strain. The future looks misty and dark.
\end{abstract}

Keywords: Monetary union, Financial crisis, Fiscal policy, Balance of payments

\section{Introduction}

This paper is intended to analyze reasons why some countries of the European Union experienced particularly strong impact of the economic and financial crisis which resulted in their undermined financial credibility. This group of countries, far from being homogenous, comprises Portugal, Ireland, Italy, Greece and Spain and it is commonly shortly called PIIGS. Greece and Ireland both experienced long-term sovereign rating downgrades twice in 2009 and Portugal and Spain once in 2009 (ECB (2010), p. 38). While ten-year government bond yields of the euro areas countries diverged in 2008 and 2009, Greek and Irish bond yields recorded the fastest growth and remained at particularly high levels (with high spreads over German bonds) (ECB (2010), p. 37). According to a popular opinion these countries were subject to particularly strong tensions in their public finances which eventually led to a serious loss of credibility. Although this opinion is not quite false, it is only partly true; the fiscal situation of these countries must be considered in a broader context which matters a lot. To justify briefly this point of view two examples might be called for; the example of the UK with double-digit public deficits and a rather high level of public debt and the example of Belgium with public debt close to $100 \%$ of GDP and still considerable public deficits. Neither of these countries experienced the same pressures which were exerted on the PIIGS.

This paper begins in its next part with a short overview of the reasons for the crisis. These reasons to a certain degree explain why the shock turned out to have an asymmetric impact on the countries of the European Union. This part of the paper also presents fiscal costs of the crisis and fiscal stimuli to boost the economies. Paradoxically, PIIGS countries were not among those running most expansionary fiscal policies.

It is the initial economic situation which matters a lot. Economic developments in the European Union before the crisis and resulting different vulnerabilities among its member countries are discussed in the third part of the paper. It is argued that - although fiscal stance and public debt are important - in the case of the countries in question there is another problem of balance of payments imbalances, which mirrors the situation of the private sector, too. This characteristic of 
the crisis is blurred by the membership of the countries in the euro zone. Having the common currency also prohibits the application of the easiest and best solution; devaluation.

The fourth part is devoted to the analysis of the economic policy in the face of the crisis. It is argued that the countries which experience negative, asymmetric developments including balance of payments imbalances are deprived of policy instruments necessary to overcome their problems. What concerns the common economic policy of the European Union it seems to be erratic, in breach of important rules which were supposed to govern economic life in the UE and in the euro zone, it neglects democratic control over public finances and - last but not least - it does not address in a perspective manner the specific problems encountered by the countries which were hit most.

The last part concludes.

\section{How the Crisis Hit the European Union Member Countries}

The reasons for the present financial and economic crises - although quite complex - are fairly well recognized and presented in the literature. They comprise hasty deregulation of the financial sector, poor supervision, wrong incentives and erroneous monetary policy. Also the development of the crisis at first in the United States and then in Europe is subject to a comprehensive description. In this part of the paper I would like to limit my remarks only to some characteristics of the crisis in the European Union, in particular to the asymmetric impact of the initial financial shock and different budgetary reaction to and costs of the crisis.

Particular countries of the EU to different extent experienced contractionary effects of the shock. Among the countries which were hit rather strongly (in terms of GDP) there are both representatives of the PIIGS group (in particular Ireland) and those which do not belong to this category (Germany). The same applies to countries where the crisis had fairly mild effects for GDP; amongst them there is Poland but also Greece which experienced the most severe loss of credibility (European Commission, 2009 (b), p. 27). According to the European Commission (2009 (b), p. 27) there are three characteristics of the economies which determined the extent to which the crisis had its contactionary effects. Firstly, it is the extent to which housing markets had been overvalued and construction industries oversized. This feature mirrors the role of the real estate market bubble in the present crisis. Its negative impact was severe in United Kingdom, France, Ireland, Spain and the Baltic countries - this group consists of both PIIGS countries and other EU members. Secondly, the impact of the shock reflected the export dependency of the economy and the current account position. In fact, this is a mixed criterion. "Countries where export demand has been strong and/or which have registered current account surpluses are more exposed to the sharp contraction of world trade (e.g. Germany, the Netherlands, and Austria). Countries which have been running large surpluses are also more likely to be exposed to adverse balance sheet effects of corrections in international financial asset markets. Conversely, countries which have been running large current account deficits may face a risk of reversals of capital flows." (European Commission, 2009 (b), p. 29) Later in the paper we will pay attention to the latter relation between current account deficits and credibility crises. Among countries with high deficits there are Portugal, Greece and Spain. The third characteristic which determined the impact of the shock on economic activity was the size of the financial sector and/or its exposure to risky assets. This criterion applies particularly to the United Kingdom and Ireland.

The first conclusion we may draw from these observations is that acute loss of credibility on international financial markets was not clearly related to the depth of the crisis in terms of GDP and that the features which determined the extent of contraction find little explanatory power in this respect.

Another explanation which obviously comes to mind is a sharp deterioration of a poor fiscal stance and high public debt (irrespective of GDP dynamics). Let's have a closer look at fiscal developments in the EU member countries during the crisis.

Table 1 and table 2 present public deficits and debts as a percentage of GDP of chosen EU countries, EU and the euro zone. The tables show a general deterioration of the balances of public finances and growth of public debt in each of the countries. Some countries experienced particularly sharp rise in public deficits. This group consists mainly of PIIGS countries. Moreover, Greece even before the crisis had high and excessive deficits.

These remarks on fiscal developments in the European Union in the wave of the crisis are far from being complete. There is broad literature - mainly published by the ECB and the European Commission - which analyses many aspects of public finances in distress. It covers contingent liabilities, factors driving government bond yield spreads, discretionary stimuli versus automatic stabilizers and a change in fiscal stance, the effectiveness of budgetary spending aimed at boosting the economy, the need for consolidation, problems due to aging societies and fiscal sustainability. This literature is very much focused on technical aspects of fiscal developments. The picture of fiscal situation in EU member countries it presents is quite precise and much more complete than what have been presented above. 
To whatever degree the analysis of fiscal developments is complete it does not necessarily mean that this is the whole story behind the credibility crisis. We still face some puzzles neglected in the literature. Let's note that the United Kingdom also recorded double-digit deficits while Italy kept its deficit at a moderate level, well below the average for the European Union and for the euro zone. The fiscal situation of the United Kingdom (comprising both deficits and debts) was not much different (at least until 2010) than that of Ireland and worse than that of Spain. Greece and Italy had very high debts but the same is true in the case of Belgium which did not experience much market pressure (and public deficits were in Belgium rather high as well). Some other countries of the PIIGS group, Spain and Ireland, had even lower debts than "benchmark" Germany or an average for the European Union and the euro zone.

I am ready to agree that the situation of public finances is an important, may be the main factor driving the development of the credibility crisis. However, this cannot be the whole picture; its analysis still leaves us with the puzzles. In the next part I will present some missing elements.

\section{Fiscal Crisis or Balance of Payments Crisis}

Before the present crisis erupted and before public finances of some member countries of the European Union get beyond control there had been some tensions within the euro area. In 2008 new problems emerged and captured public interest but these old tensions did not necessarily disappeared; conversely, they seem to be closely interlinked with the present fiscal crisis of some EU member countries.

The mechanism of these tensions started in some countries of the monetary union with the reaction of market participants, particularly consumers, to lower interest rates due to participation in the euro area. As a result the economy became overheated and inflation was slightly but persistently higher in these countries than the average for the euro area (European Commission, 2001). Eventually, it brought about considerable "real exchange rate" appreciation or loss of international competitiveness (European Commission, 2005, Wyplosz, 2006, 2006(b)). Current account deficits emerged/increased. As foreign liabilities grew, possibilities to further accumulate the debt and run current account deficits came closer to a limit. In the absence of foreign exchange rate it eventually calls for a decline in private and/or public spending. As a consequence the economy stagnates (Koronowski, 2009). Of course, this mechanism creates some pressure to cut public spending, either as a means to alleviate current account imbalances or simply to keep public deficits under control, especially in line with the provisions of the Stability and Growth Pact.

The PIIGS countries perfectly match the above scenario. In 1999 - 2006 the competitiveness of the economy (versus other countries of the euro area) declined by $27 \%$ for Italy, by $12 \%$ for Spain and by $10 \%$ for Greece. Portugal and Ireland also suit the general pattern although some additional factors played a role there (Wyplosz, 2006b, Basto, 2007, Koronowski, 2009).

Here we come to the missing elements of the puzzle, which is current account deficits, high foreign liabilities and resulting vulnerabilities of the economies. This problem is also recognized, although in a rather weak form, by the European Commission (2009, p. 193): "The loss of the exchange rate as an adjustment instrument may imply protracted periods of self-reinforcing destabilising dynamics due to price and wage rigidities. Current account imbalances and net foreign asset positions can in turn play an important role in a context of exacerbated tensions in financial markets."

The same problem was recognized by Visser $(1995$, p. 136) in the context of the theory of optimum currency areas. In his critique of Ingram's opinion that a high degree of financial integration should be an argument in favor of a currency area (a criterion of the optimum currency area) Visser wrote: "If, for instance, diverging cost developments cause chronic sizeable current-account imbalances, wealth holders may at some point refuse to accumulate the debt of the deficit country. Capital inflows dry up and speculative attacks against the currency of the deficit country are to be expected, forcing devaluation." Visser formulates his reservations in the traditional optimum currency area terms of fixed exchange rates and possible devaluations. In a monetary union there couldn't be a speculative attack against a currency or devaluation but wealth holders may still refuse to further accumulate the debt of the deficit country, in particular its government or financial institutions. In this juncture, there is no exchange rate risk which could spur investors to sell the currency of the deficit country but credit risk matters and it is even exacerbated by the absence of the exchange rate adjustment mechanism; it would be very difficult to service (foreign) debt as long as there is no improvement in the current account/domestic savings. It pertains to both public and private debtors, the problem has a macroeconomic dimension that relates to incomes and savings and eventually determines the ability of domestic agents to service their debts. Government bond markets would be usually most liquid and would react most abruptly. High government liabilities and deficits themselves may obviously be subject to increased risk and investors' nervousness. However, current account deficits may crucially worsen the situation. Imposing higher taxes on private agents who barely service their own debts and who are inclined to borrow even more in spite of tough market conditions would be rather difficult and dangerous. Any attempt to cut spending would badly influence incomes and exacerbate the situation of private borrowers and financial institutions. 
Investors may not only refuse to further accumulate the debt but they may be also strongly inclined to sell risky assets of the deficit country. In the context of the credibility crisis in the EU it was ECB's enormous purchases of Greek bonds, discussed in the third part of the paper, that enabled investors to sell these risky assets without major losses and plummeting prices. "By buying up Greek debt, the ECB keeps the prices of the bonds artificially high. French banks, in particular, benefit from this policy because it enables them to sell their Greek bonds to the ECB, as an inexpensive way of cleaning up their balance sheets." (Reuter, 2010)

In light of the above remarks it seems reasonable to analyze the empirical evidence of the European Union. Table 3 presents current account deficits of some European Union member countries and table 4 contains data on net international investment positions.

The data in the tables show that countries which experienced most market pressure and which in particular were subject to rating downgrades had not only poor fiscal situation but also - and probably first of all - high or extreme and persistent current account deficits and very big negative net international investment positions. This is the case of Greece, Spain and Portugal. An exception in the PIIGS group is Ireland which had its government bonds spreads roaring in spite of a fairly good external position. In this case other factors, particularly very high exposure to financial losses, seem to have played a major role. Conversely, neither Belgium, nor the UK experienced strong market pressures in spite of their very poor fiscal positions (extremely high public debt/high deficit and enormous deficit/high debt respectively). Also Italy was "saved" although it reached a record in public debt level; however it had still moderate current account deficits, not particularly high public deficits and quite good net international investment position.

These examples show there is no direct link between fiscal situation and external position. Although "twin deficits" mechanism might have played an important role, the developments in the private sector seem to be meaningful. Current account deficits and foreign debt may also result from high spending and borrowing of households, in particular. Table 5 presents data on increases in household liabilities in chosen EU member countries between year 2000 and 2008 . Table 6 contains data on households net saving rates as a percentage of disposal income.

The data from tables 5 and 6 show big differences among the countries. When it comes to increases in household liabilities, there is a group of countries with particularly high rates. This is Hungary, Poland and the Czech Republic, the representatives of the countries which had their economies reemerging from the communist era, with fast remonetization as a part of it. As table 6 shows it was not combined with particularly low saving rates. I don't want to claim that the rise in the liabilities was never dangerously fast but neither in Poland nor in the Czech Republic it brought about internal financial tensions or current account imbalances. In the case of Hungary (and some other countries of the region), however, there were clear problems having the nature of the balance of payments crisis.

Another country which had outstanding rate of growth of households liabilities was Greece. This is in line with high negative saving rates in this country. Most importantly, it is in perfect harmony with its catastrophic external position. Other countries with very low, sometimes also negative, saving rates are the United Kingdom and Portugal. In the case of Portugal low saving rates are not mirrored in particularly high growth in liabilities (which deserves further research) but it again is well expressed in very high current account deficits. The case of the UK is different with respect to current account deficits: they remained on a moderate level.

To explain the difference between Greece and Portugal and the United Kingdom it is reasonable to point out that the UK still have it own currency; the pound sterling lost about one third of its value versus the euro between January 2007 and October 2010. Earlier in this paper we noticed also a good international investment position of the country. In fact it turned positive only in 2008 which reflects capital outflow from the United Kingdom. In a way, this country was subject to a mild credibility and currency crisis.

Other countries of which data are in the tables above had fairly modest rates of growth in households liabilities and reasonably high saving rates. This group includes in particular remaining PIIGS countries. Spanish current account deficits seem to be more related to public deficits than to the developments in the private sector. In the case of Ireland and Italy as external positions remained fairly good.

This analysis shows that it is difficult to group countries as they have individual distinctive features. This reservation pertains also to PIIGS group propitiously declared in the media. However, it is easy to notice, that credibility crisis is often combined with serious balance of payments problems (Greece, Portugal, Spain). An exemption is Ireland and - to a degree - Italy which, however, didn't experience particularly strong negative market pressure. Current account imbalances are most often interlinked with high public deficits but in some cases (Greece, Portugal) the developments in the private sector seem to play an important role. Finally, a major difference is having its own currency or being a member in the euro area. Countries which are in the monetary union of course are saved from a classic currency crisis. 
This does not change the fact that they experience a balance of payments crisis with no simple - even if unpopular remedy of devaluation. This is the case of Greece, Portugal, Spain, and to a lesser degree Italy. Also Estonia seems to match perfectly well this group. The other cluster contains of countries with high fiscal deficits and excessive private spending, which preserve their currencies and flexible exchange rates such as the United Kingdom and Hungary. In these countries the adjustment mechanism of exchange rates operates. Sometimes the adjustment is smooth and sometimes abrupt what reflects distinctive features of particular countries, their international credibility and liquidity of respective financial markets.

The observations made in this part of the paper show that acute credibility problems emerge where fiscal tensions come hand in hand with current account imbalances. In the euro area this kind of crisis finds no easy remedy. In the next part we will consider if economic policy in the monetary union offers a relief.

\section{Policy Response to the Crisis: Can it Overcome Asymmetries?}

In the wave of the crisis there came an urgent need to support wobbly financial institutions and avoid a systemic collapse. This action took many forms which demanded either direct injection of public money or giving public guaranties. This cost was quite high in terms of GDP and brought about a considerable rise in public debt in some countries. Among members of the euro zone Netherlands, Ireland, Luxembourg and Belgium were hit most; due to financial stabilization operations public debt rose in these countries in 2008-9 respectively by $11.4 \%$ of GDP, $6.7 \%$ of GDP, $6.6 \%$ of GDP and $6.4 \%$ of GDP. With the exemption of Ireland none of these countries were subject to major market pressure. What concerns other PIIGS group members the number for Greece was 1.6, for Spain 1.8, for Portugal it was 0.0 and for Italy 0.1 ; for all these countries it was lower than the average for the euro area $(2.5 \%$ GDP). Also the impact of cumulated stabilization operations on government contingent liabilities for all PIIGS countries were lower than the euro area average with the striking exemption of Ireland (ECB, 2010, p. 15). Ireland was the only country which experienced a major credibility problems and had high financial sector stabilization costs. These costs certainly were not a reason for bad market sentiment in the case of other PIIGS group countries. Moreover, these countries which incurred the highest costs of financial stabilization did not suffer much loss of credibility (except Ireland).

On 26 November 2008, the European Commission launched the European Economic Recovery Plan (EERP) with an aim to provide a coordinated short-term budgetary impulse to demand. It is a unique example of short-sighted economic policy which called for fiscal expansion without any respect for clear signs of either major imbalances in public finances of many member countries or their alarming current account deficits. It is also highly disputable if this plan was not in a major conflict with state aid rules enshrined in the Treaty (art. 126). Finally, this plan took no serious consideration of the Stability and Growth Pact which - as usually - allows enough room for interpretations by the mighty. It is not a surprise that this plan very quickly had to give room to fiscal "consolidation".

Any activist fiscal stimuli did not play an important role in deteriorating fiscal situation of the countries which experienced most market pressure. It is not an easy task to divide changes in budget deficits into different components such as automatic stabilizers, other cyclical components and activist change in fiscal stance, including expenditures which are clearly dedicated to alleviate the crisis. However, countries which underwent most market pressure and loss of credibility, PIIGS group in particular, don't seem to have been especially devoted to activist fiscal policies, probably with some exemption of Spain. The value of fiscal stimuli packages in Greece and Italy was zero and in Ireland and Portugal it was well below the average for the euro area both in 2009 and 2010. In fact, these countries had little room for any fiscal expansion or activism.

Since I used above a term "room for fiscal expansion" it makes sense to refer to a similar notion of "fiscal space". According to Heller (2005) this is "room in a government's budget that allows it to provide resources for a desired purpose without jeopardizing the sustainability of its financial position or the stability of the economy." (European Commission, 2009, p. 182) "Fiscal space" is subject to constructing an index which makes it measurable. It matters here that the index comprises not only explicit fiscal characteristics (government debt, contingent public liabilities to the financial sector, estimates of foreseeable revenue shortfalls, share of non-discretionary public expenses) but also current account balance. This seems to well combine both fiscal and current account imbalances referred to in the previous part of the paper. However, since the index integrates both aspects, "fiscal space" is not useful to present their relative "contribution" to credibility problems. Moreover, the index does not take into consideration actual public deficits which determine possibilities to further expand fiscal policy and - of course - have an essential meaning for credibility. It would be wrong to interpret the notion and the index as if the imbalances could be reduced to the fiscal dimension, either. Values of the index for the European Union member countries are presented in (European Commission, 2009, p. 185).

What concerns the monetary policy of the ECB it was conventionally very easy during the crisis. However, such policy obviously cannot solve the asymmetric problems of some member countries of the monetary union. It would not help to 
reduce either public deficits or current account deficits of the countries which face such imbalances. Fortunately, low interest rates at least moderate the burden of interest rate payments of most indebted government/countries.

Even in this juncture the ECB found a rather unconventional way to deal with the credibility crisis. In May 2010 it engaged on a huge scale in buying up government bonds of the countries which faced the credibility problems most severely, Greece in particular (Reuter, 2010). The ECB did so not for any monetary policy reasons, the action was clearly a market intervention intended to bail out countries under strong market pressure and to alleviate financial strains which could lead to big losses of commercial banks. This way the ECB assumed a role of a "bad bank". Certainly, it did not have a good effect for its reputation. In a way it helped to calm down the situation and buy some time for any further policy action. However, it is not an easy question what this policy action should be like. Obviously, there are strong claims that problematic countries need particularly tough policy to balance their budgets which is much easier said than done.

The ECB's support came in the same time when the euro zone countries' $€ 110$ bailout package for Greece started. This package was clearly a breach of "no bailout clause" worshipped since the creation of the monetary union. This package also only preceded (and was a part of) a much larger, $€ 750$ program of the European Commission (co-financed by the IMF) which were to guarantee the emission of euro-obligations should a need for further support emerge. The program is not very precise; it is not quite clear what amounts of money particular member states declared (Glapiak, 2010). It is even more important that governments acquired huge contingent liabilities beyond any democratic procedures. This was subject to constitutional complaint in Germany; however, the case was dismissed by the constitutional court.

Countries which have big external debts, excessive current account deficits, accompanied by high public deficits and public debts have no easy solutions to their problems in the monetary union. Fiscal "consolidation" may be a reasonable postulate but the reason for which the problems are so severe in some countries is not their particularly strong fiscal expansion; fiscal consolidation is certainly not the remedy. Their weak fiscal stance is rather more an effect than a cause of the economic downturn and external imbalances. The trouble is that these countries which face negative, asymmetric developments have no economic instruments to deal with their problems; they gave up individual monetary and exchange rate policy. Moreover, it would not be easy to cut spending or raise taxes now when these economies are deeply in the crisis. "Greek fiscal consolidation plans will be very difficult to execute. They assume budgetary spending savings of $5.25 \%$ GDP and increased incomes due to higher taxes equal to $4 \%$ of GDP (...). In spite of that public debt would reach $150 \%$ of GDP and interest rate payments (calculated at a moderate interest rate $5 \%$ ) would reach $7.5 \%$ GDP (...). Such adjustment would have to be backed by a considerable growth in exports what is difficult to imagine in a country which has no power to devalue its currency and which does not have big export potential" (Wołowiec, 2010, transl. A.K.).

The European Union can offer only bailout packages initiated by some member states, the Commission and the ECB. These programs bring about a major erosion of the rules which were to govern the community and they only allow to buy time while no actual solutions emerge. In this juncture it would be interesting - and rather frustrating - to ask questions about the future; the prospects do not seem bright (Lacina, Rusek, 2010).

\section{Conclusions}

Fiscal situation in member states of the European Union worsened dramatically in the wave of the financial and economic crisis. High public debts and big public deficits are popularly recognized as a reason for credibility crisis that hit some of the countries. However, a closer look proves that fiscal situation is not the dominant factor which drives market sentiments. Extended fiscal positions gain weight only when combined with considerable net foreign liabilities and unsustainable current account deficits. External imbalances reflect not only unbalanced public finances but also excessive spending of the private sector. Moreover, these countries which experienced strong pressures generally did not run activist fiscal policies aimed at stimulating the economy. The credibility crisis is not only a fiscal crisis, it is in the first place a balance of payments crisis.

In this juncture fiscal "consolidation" does not seem to be a remedy to the problems. It would reduce imbalances in public finances and it could help cut current account deficits. It is highly improbable, however, that the countries which face credibility problems and which are deeply in the economic crisis could pursue adequate plans to balance their budgets; this is in fact the reason why their credibility is low. Since the external imbalances matter crucially, devaluation could help to regain international competitiveness, improve current accounts, boost the economies and increase revenues of the budget. Unfortunately, this is not possible in the euro zone.

Instead, the economic policy of the ECB, the European Commission and particular member states of the European Union versus problematic countries is restricted to different forms of bailout programs. It violates the declared principles 
of the monetary union, it strains legal foundations of the European Union, it is pursued with no respect for the democratic control over public finances and - eventually - it does not solve the problems.

\section{References}

Basto, R.B. (2007). The Portuguese Experience with the Euro - Relevance for New EU Member Countries, Bank i Kredyt, No 11-12/2007

Blanchard, O. (2006). Is There a Viable European Social and Economic Model, MIT Department of Economics Working Paper Series 06-21

ECB. (2010). Euro Area Fiscal Policies and the Crisis, Occasional Paper Series, No 109, Apri1/2010

European Commission . (2001). Policy adjustment in the euro-area countries: the risk of overheating. In The EU Economy: 2001 Review

European Commission. (2005). Growth differences in the euro area, in Quarterly Report on the Euro Area, IIq./2005

European Commission. (2009). Public Finances in EMU, 2009, European Economy 5/2009

European Commission. (2009b). Economic Crisis in Europe; Causes, Consequences and Responses, European Economy $7 / 2009$

Glapiak, E. (2010). 115 miliardów na pomoc zadtużonej Europie?, Rzeczpospolita, 14.06.2010

Heller, P.S. (2005). Understanding fiscal space, IMF Policy Discussion Paper 05/4

Koronowski, A. (2009). Divergent business cycles as an effect of a monetary union, International Economics and Economic Policy, vol. 6 no 2

Lacina, L., Rusek A. (2010), Financial Crisis and its Asymmetric Macroeconomic Impact on Euro-zone Member Countries, a paper presented at $69^{\text {th }}$ IAES Conference, Prague

Reuter, W. (2010) ECB Buying Up Greek Bonds; German Central Bankers Suspect French Intrigue, SpiegelOnline International, May 31, 2010 (http://www.spiegel.de/international/europe/0,1518,697680,00.html)

Visser, H. (1995), A Guide to International Monetary Economics, Exchange Rate Systems and Exchange Rate Theories, Edward Elgar, Cambridge

Wołowiec, T. (2010). Finanse publiczne i gospodarka polska - wplyw zjawisk kryzysowych, kierunki reform $i$ perspektywy wzrostu, WSB NLU, Nowy Sącz

Wyplosz, Ch. (2006). European monetary union, the dark side of a major success, Economic Policy, April 2006

Wyplosz, Ch. (2006b). Diverging tendencies of competitiveness. Briefing notes to the Committee for Economic and Monetary Affairs of the European Parliament 
Table 1. General government deficits/surpluses of chosen EU member countries, EU and euro zone, \%GDP

\begin{tabular}{|c|c|c|c|}
\hline & 2007 & 2008 & 2009 \\
\hline Belgium & -0.2 & -1.2 & -6.0 \\
\hline Czech Rep. & -0.7 & -2.7 & -5.9 \\
\hline Germany & 0.2 & 0.0 & -3.3 \\
\hline Ireland & 0.1 & -7.3 & -14.3 \\
\hline Greece & -5.1 & -7.7 & -13.6 \\
\hline Spain & 1.9 & -4.1 & -11.2 \\
\hline France & -2.7 & -3.3 & -7.5 \\
\hline Italy & -1.5 & -2.7 & -5.3 \\
\hline Netherlands & 0.2 & 0.7 & -5.3 \\
\hline Austria & -0.6 & -0.4 & -4.0 \\
\hline Poland & -1.9 & -3.7 & -7.1 \\
\hline Portugal & -2.6 & -4.9 & -9.4 \\
\hline Sweden & 3.8 & 2.5 & -0.5 \\
\hline UK & -2.8 & -4.9 & -11.5 \\
\hline EU & -0.8 & -2.0 & -6.8 \\
\hline Euro zone & -0.6 & -2.0 & -6.3 \\
\hline & & & \\
\hline & & & -1.5 \\
\hline
\end{tabular}

Source: Eurostat data

Table 2. General government debt of chosen EU member countries, EU and euro zone, \%GDP

Source: Eurostat data

\begin{tabular}{|c|c|c|c|}
\hline & 2007 & 2008 & 2009 \\
\hline Belgium & 84.2 & 89.8 & 96.7 \\
\hline Czech Rep. & 29.0 & 30.0 & 35.4 \\
\hline Germany & 65.0 & 66.0 & 73.2 \\
\hline Ireland & 25.0 & 43.9 & 64.0 \\
\hline Greece & 95.7 & 99.2 & 115.1 \\
\hline Spain & 36.2 & 39.7 & 53.2 \\
\hline France & 63.8 & 67.5 & 77.6 \\
\hline Italy & 103.5 & 106.1 & 115.8 \\
\hline Netherlands & 45.5 & 58.2 & 60.9 \\
\hline Austria & 59.5 & 62.6 & 66.5 \\
\hline Poland & 45.0 & 47.2 & 51.0 \\
\hline Portugal & 63.6 & 66.3 & 76.8 \\
\hline Sweden & 40.8 & 38.3 & 42,3 \\
\hline UK & 44.7 & 52.0 & 68.1 \\
\hline EU & 58.8 & 61.0 & 73.6 \\
\hline Euro zone & 66.0 & 69.7 & 79.0 \\
\hline
\end{tabular}


Table 3. Current account deficits of chosen EU member countries, \%GDP

\begin{tabular}{|c|c|c|c|c|}
\hline & 2005 & 2006 & 2007 & 2008 \\
\hline Belgium & 2.6 & 2.0 & 2.1 & -2.4 \\
\hline Czech Rep. & -1.3 & -2.5 & -3.3 & -3.1 \\
\hline Germany & 5.1 & 6.5 & 7.9 & 6.7 \\
\hline Ireland & -3.5 & -4.4 & -5.3 & -5.3 \\
\hline Greece & -7.5 & -11.2 & -14.4 & -14.6 \\
\hline Spain & -7.4 & -9.0 & -10.1 & -9.6 \\
\hline France & -0.4 & -0.5 & -1.0 & -2.2 \\
\hline Italy & -1.7 & -2.6 & -2.4 & -3.4 \\
\hline Netherlands & 7.3 & 9.3 & 7.7 & 7.5 \\
\hline Austria & 2.1 & 2.4 & 3.6 & 3.2 \\
\hline Poland & -1.2 & -2.8 & -4.7 & -5.5 \\
\hline Portugal & -9.5 & -10.1 & -9.5 & -11.2 \\
\hline Sweden & 7.0 & 8.5 & 8.6 & 8.4 \\
\hline UK & -2.6 & -3.3 & -2.7 & -1.7 \\
\hline
\end{tabular}

Source: IMF data

Table 4. Net International Investment Positions of chosen EU member countries, approximated , \% GDP, 2008 (Ireland 2007)

\begin{tabular}{|lccc|lc|lc|c|}
\hline Belgium & 40 & Czech Rep. & -31 & Germany & 31 & Ireland & -23 & Greece \\
\hline France & -23 & Italy & -14 & Netherlands & 16 & Austria & -15 & Poland \\
\hline Spain & -81 & Portugal & -84 & Sweden & 8 & UK & 6 & Hungary \\
\hline
\end{tabular}

Source: own calculations, IMF and OECD data

Table 5. Households liabilities (loans) in chosen EU member countries, approximated, 2008 (100 for 2000)

\begin{tabular}{|c|c|c|c|c|c|c|c|c|c|}
\hline Belgium & 168 & Czech Rep. & 543 & Germany & 101 & Ireland & 331 & Greece & 694 \\
\hline France & 191 & Italy & 233 & Netherlands & 196 & Austria & 151 & Poland & 771 \\
\hline Spain & 315 & Portugal & 209 & Sweden & 204 & UK & 215 & Hungary & 1244 \\
\hline
\end{tabular}

Source: own calculations, OECD data 
Table 6. Households net saving rates as a percentage of households disposable incomes

\begin{tabular}{|c|c|c|c|c|}
\hline & 2005 & 2006 & 2007 & 2008 \\
\hline Belgium & 9.7 & 10.9 & 11.4 & 12.0 \\
\hline Czech Rep. & 3.2 & 4.8 & 6.3 & 5.8 \\
\hline Germany & 10.5 & 10.5 & 10.8 & 11.2 \\
\hline Ireland & 5.6 & 3.8 & 2.7 & 4.1 \\
\hline Greece & -8.0 & -7.3 & $\ldots$ & $\ldots$ \\
\hline Spain & 4.7 & 4.2 & 3.6 & 6.1 \\
\hline France & 11.4 & 11.4 & 12.0 & 11.6 \\
\hline Italy & 9.9 & 9.1 & 8.2 & 8.6 \\
\hline Netherlands & 6.3 & 6.0 & 8.1 & 6.8 \\
\hline Austria & 9.7 & 10.9 & 11.4 & 12.0 \\
\hline Poland & 7.1 & 6.8 & 7.4 & $\ldots$ \\
\hline Portugal & 2.5 & 1.1 & -1.1 & -0.9 \\
\hline Sweden & 6.8 & 7.8 & 9.1 & 12.1 \\
\hline UK & -1.3 & -2.9 & -4.3 & -4.5 \\
\hline
\end{tabular}

Source: OECD data 